\title{
Profil Leukosit Rusa Timor (Cervus timorensis) Betina pada Tiap Fase Berahi yang Disuplementasi Magnesium (Mg), Zinc (Zn), dan Selenium (Se)
}

\author{
Leukocyte Profiles of Female Timor Deer (Cervus timorensis) within Each Estrous Phase \\ which is Supplemented by Magnesium (Mg), Zinc (Zn), and Selenium (Se)
}

\section{R. Indriastuti, D. Samsudewa, dan Y. S. Ondho}

\author{
Fakultas Peternakan dan Pertanian Universitas Diponegoro, Semarang \\ Corresponding e-mail: rhestyindri@yahoo.co.id
}

\begin{abstract}
The objective of this research were to determine the effects of Magnesium ( $\mathrm{Mg})$, Zinc ( $\mathrm{Zn})$, and Selenium (Se) supplementation on Timor deer's total leukocytes and the differential of leukocyte (neutrophils, eosinophils, basophils, monocytes, and lymphocytes percentage) on estrous phase of Timor deer. The material used 10 females Timor deer and the blood of each deer. They were adapted for 2 days, then 5 females Timor deers were treated $\mathrm{Mg}, \mathrm{Zn}$, and Se supplementation (T1) and control (T0) for 8 weeks. To obtain a uniform estrous, estrous synchronization performed using Medroxy Progesterone Acetat (MPA) for 16 days. Blood sample was collected on estrous phase for blood mineral analysis, and calculating total leukocytes count and the differential of leukocyte. The data were analyzed by T-test and Mann Whitney U-test. Statistical analysis showed that total leukocytes and the differential had no significant difference $(\mathrm{p} \geq 0.05)$ between $\mathrm{T} 0$ and $\mathrm{T} 1$. It was concluded that all parameters showed the highest value on estrous phase, except the percentage of eosinophils and monocytes, it showed the highest value on diestrous and metestrous phase. $\mathrm{Mg}, \mathrm{Zn}$ and $\mathrm{Se}$ supplementation had no significant effect on changing the Timor deer's total leukocytes and the differential leukocyte.
\end{abstract}

Keywords: Timor Deer, leukocytes, estrous, mineral supplementation.

\begin{abstract}
ABSTRAK
Penelitian ini bertujuan untuk mengetahui pengaruh suplementasi Magnesium (Mg), Zinc (Zn), dan Selenium (Se) terhadap total leukosit dan diferensial leukosit (persentase neutrofil, eosinofil, basofil, monosit, dan limfosit) Rusa Timor pada tiap fase berahi. Materi yang digunakan adalah 10 ekor Rusa Timor betina dan darah dari masing-masing rusa tersebut. Rusa diadaptasikan dan sebanyak 5 ekor diberi perlakuan suplementasi $\mathrm{Mg}, \mathrm{Zn}$, dan Se (T1) dan kontrol (T0) selama 8 minggu. Rusa disinkronisasi berahinya menggunakan implan Medroxy Progesteron Acetat (MPA) selama 16 hari. Sampel darah diambil pada tiap fase berahi untuk dianalisis kandungan mineral darah serta dihitung total leukosit dan diferensial leukositnya. Analisis data menggunaakan metode Ttest dan Mann Whitney U-test. Hasil analisis statistik menunjukkan bahwa total leukosit dan diferensial leukosit Rusa Timor tidak berbeda nyata $(\mathrm{p} \geq 0.05)$ pada kedua kelompok. simpulan yang diperoleh adalah hampir semua parammeter menunjukkan nilai tertinggi pada fase estrus, kecuali eosinofil dan monosit yang tinggi pada fase diestrus dan metestrus. $\mathrm{Mg}, \mathrm{Zn}$, dan Se tidak berpengaruh nyata dalam merubah jumlah leukosit dan diferensial leukosit Rusa Timor.
\end{abstract}

Kata kunci: Rusa Timor, leukosit, estrus, suplementasi mineral.

\section{PENDAHULUAN}

Estrus merupakan fase dengan kemungkinan invasi bakteri sangat besar. Kondisi servik akan membuka sebagai jalan masuk sperma saat proses perkawinan. Masuknya penis jantan pada perkawinan alami, serta AI (Artificial Insemination) gun pada perkawinan buatan menjadi peluang besar masuknya bakteri dan dapat berkembang di saluran reproduksi betina. Sel darah putih (leukosit) berperan dalam sistem imunitas guna mencegah infeksi saluran reproduksi akibat bakteri tersebut. Leukosit, beserta sel turunannya, neutrofil, eosinofil, basofil, monosit dan limfosit akan mengidentifikasi, mengklasifikasi dan melenyapkan (fagositosis) bakteri, virus serta bahan asing lainnya. 
Standar jumlah leukosit darah sekitar 4.000-10.000/ $\mu \mathrm{L}$ (Kurniawan et al., 2015). Jumlah leukosit di atas atau di bawah standar normal mengindikasikan ada ketidak normalan anatomi maupun fisiologis suatu individu. Total leukosit Rusa Timor adalah $2.950-4.050 / \mu \mathrm{L}$ (Tjendrajaja, 2011), dan 8.000-10.000 sel pada Rusa Indian (Shanti et al., 2012).

Jumlah leukosit yang normal menggambarkan bahwa ternak sehat dan tidak terdapat infeksi, termasuk pada saluran reproduksi. Ternak dengan organ reproduksi yang sehat dapat mencapai efisiensi reproduksi, artinya berpeluang meningkatkan populasi dalam waktu singkat. Tentunya hal ini sangat penting dalam manajemen pemeliharaan Rusa Timor sebagai salah satu jenis satwa harapan. Populasi Rusa Timor yang masih rendah di Indonesia diharapkan meningkat signifikan melalui angka kelahiran/tahun yang tinggi. Demi mencapai tujuanini, hendaknya kondisi reproduksi Rusa Timor selalu sehat tanpa ada infeksi.

Waktu kawin pada fase estrus memungkinkan masuknya banyak bakteri ke saluran reproduksi betina. Pada fase ini, estrogen akan memicu produksi leukosit guna mencegah infeksi. Peningkatan leukosit ini hendaknya tidak menimbulkan leukositosis, sehingga perlu suatu upaya dalam mengendalikannya, salah satunya melalui suplementasi mineral. Diketahui bahwa dinamika jumlah leukosit dan diferensialnya dapat dikendalikan dan dipengaruhi fungsinya oleh unsur mineral dalam tubuh, seperti $\mathrm{Mg}, \mathrm{Zn}$, dan Se. Penambahan $\mathrm{Zn}$ sebesar 60 ppm meningkatkan jumlah sel leukosit sapi Frisian Holstein (Widhyari et al., 2014). Oleh sebab itu, perlu dilakukan penelitian mengenai efektivitas penambahan mineral $\mathrm{Mg}, \mathrm{Zn}$, dan Se terhadap profil leukosit Rusa Timor betina pada tiap fase berahi.

Tujuan penelitian ini adalah untuk mengetahui pengaruh suplementasi mineral ( $\mathrm{Mg}, \mathrm{Zn}$, dan $\mathrm{Se}$ ) terhadap total leukosit dan diferensial leukosit Rusa Timor pada tiap fase berahi. Penelitian ini diharapkan mampu memberikan informasi kepada penangkar maupun peneliti lanjutan bahwa suplementasi mineral $\mathrm{Mg}$, $\mathrm{Zn}$, dan Se dalam pakan berperan dalam mengontrol jumlah leukosit dan diferensial selnya sebagai gambaran status kesehatan Rusa Timor.

\section{MATERI DAN METODE}

Penelitian dilaksanakan pada tanggal 10 Maret sampai dengan 31 Mei 2016 di penangkaran Rusa Timor milik H. Yusuf Wartono di desa Margorejo, kecamatan Dawe, kabupaten Kudus. Analisis kadar mineral darah dilakukan di Laboratorium Gizi Pusat Antar Universitas (PAU) Universitas Gadjah Mada Yogyakarta.

\section{Materi}

Materi yang digunakan adalah sepuluh ekor rusa timor betina dan darah dari masing-masing rusa tersebut. Rusa dipilih berdasarkan kriteria sehat, tidak cacat, sudah pernah partus, memiliki BCS 2-3,25 dan sudah poel 2.

Alat dalam pembuatan mineral blok terdiri dari alat pencetak, ember, kuas, gelas, tongkat penekan, sendok, gelas ukur 1000 $\mathrm{ml}$, timbangan kapasitas $5 \mathrm{~kg}$, timbangan analitik, oven, blender, dan sendok pengaduk dengan bahan-bahan berupa kertas minyak, air, minyak sayur, sabun cair, bekatul, molasses, onggok, garam, bungkil kedelai, vitamin (A, D, E, dan $\mathrm{K})$, dan mineral ( $\mathrm{Mg}$, $\mathrm{Zn}$, dan Se).

Alat dalam pemberian obat penenang adalah tulup, gas korek, spuit $3 \mathrm{cc}$, kikir, pinset, karet, serta jarum suntik ukuran 18 G.Bahan-bahannya adalah alkohol, Castran, lem, ban karet, dan benang wol.

Alat-alat untuksinkronisasi berahi adalah pencetak spon, jarum, benang, mangkok, kotak pengering, spekulum, dan aplikator. Bahan yang digunakan adalah sabun cair, Medroxy Progesterone Acetat (MPA), ethanol, aquabidest, spuit $10 \mathrm{cc}$, spon, tisu, alkohol 70\%, gloves, betadine salep, dan KY jell.

Alat-alat dalam pengambilan darah adalah penutup mata, tali, spuit $10 \mathrm{cc}$, tabung 
EDTA, tabung non-EDTA, cooling box, serta ice pack. Bahan yang digunakan adalah kapas dan alkohol 70\%.

Alat-alat untuk memperoleh serum darah adalah sentrifuge, tabung EDTA, tabung non-EDTA, spuit $3 \mathrm{cc}$, eppendorf 1.5 $\mathrm{ml}$, plastik klip, cooling box,ice pack, dan freezer. Bahan yang digunakan adalah kertas label dan sampel darah.

Alat-alat untuk menghitung total leukosit adalah tabung EDTA, cooling box, ice pack, pipet hisap darah, bilik hitung hemocytometer neubauer, cover glass, mikroskop, alat tulis, dan lembar pengamatan. Bahan yang digunakan adalah sampel darah, dan larutan Turk.

Alat yang digunakan dalam penghitungan diferensial leukosit adalah tabung EDTA, cooling box, ice pack,object glass, slide box, mikroskop, stik kecil, alat tulis dan lembar pengamatan. Bahan yang digunakan adalah kertas label, sampel darah, methanol, giemsa, aquadest, tisu, dan minyak imersi.

\section{Metode}

Penelitian dibagi menjadi tiga tahap, yakni persiapan, pelaksanaan, dan analisis data.Tahap persiapan diawali dengan menyiapkan dua kandang pengamatan dan memilih sampel rusa sesuai kriteria yang telah ditentukan dengan pembagian lima ekor rusa pada setiap kandangnya. Kemudian membuat mineral blok sebagai pakan perlakuan dengan formulasi lengkap disajikan pada Tabel 1. Selain itu, juga dibuat spuit modifikasi untuk pemberian obat penenang, serta spon vagina (MPA) untuk sinkronisasi berahi.

$$
\text { Penelitian dimulai dengan }
$$
pengadaptasian pakan rusa selama 2 hari, lalu diambil darah sebagai data awal mineral darah. Rusa diberi pelakuan suplementasi $\mathrm{Mg}, \mathrm{Zn}$, dan Se dalam bentuk mineral blok selama 8 minggu, lalu diambil darah kembali setelah perlakuan dengan diberikan obat penenang terlebih dahulu setiap akan dilakukan pengambilan darah.
Tabel 1. Formulasi mineral blok

\begin{tabular}{llc}
\hline No. & \multicolumn{1}{c}{ Bahan } & Persentase \\
\hline & & $----(\%)---$ \\
\cline { 2 - 2 } 1. Molasses & 35 \\
2. Bekatul & 40 \\
3. Bungkil Kedelai & 10 \\
4. & 6 \\
5. Onam & 6,9 \\
6. & Vit A, D, E, dan K & 0,04699 \\
& Mineral & \\
& Premix & 2 \\
Mg & 0,05 \\
Zn & 0,003 \\
Se & 0,00001 \\
\hline Total & 100 \\
\hline
\end{tabular}

Rusa disinkronisasi berahinya dengan pemasangan implan MPA selama enam 16 hari. Setelah spon vagina dilepas darah diambil berdasarkan tiap fase berahi, yaknisetelah spon vagina dilepas pada jam ke-0 (diestrus); jam ke-24 (proestrus); jam ke-72, 84, 96, dan 108 (estrus); serta jam ke120 dan 144 (metestrus) untuk dilakukan perhitungan total leukosit dan diferensialnya.

Data total leukosit, persentase neutrofil, eosinofil, basofil, monosit, dan limfosit diuji normalitas dan homogenitas, kemudian dilakukan uji lanjutan dengan metode T-test dan Mann Whitney U-test. Analisis statistik dilakukan menggunakan aplikasi SPSS 16.0.

\section{HASIL DAN PEMBAHASAN}

Berdasarkan hasil penelitian diketahui bahwamasing-masing materi penelitian memiliki panjang fase berahi yang berbeda.

\section{Total leukosit}

Berdasarkan hasil penelitian diketahui bahwa total leukosit rusa timor menunjukkan nilai normal, kecuali pada beberapa individu kelompok T0. Tabel tersebut juga menunjukkan bahwa pada kelompok T0, rata-rata total leukosit fase diestrus menunjukkan nilai cukup rendah dan semakin menurun pada fase proestrus, meningkat drastis pada fase estrus, kecuali 
pada estrus awal (72 jam setelah spon vagina dilepas) yang justru sangat rendah. Pada fase metestrus jumlah sel darah ini masih cukup tinggi, khususnya pada awal fase metestrus (120 jam setelah spon vagina dilepas). Rendahnya jumlah leukosit pada estrus jam ke-72 disebabkan karena estrogen belum mencapai puncaknya (masih dalam konsentrasi rendah dalam darah), sehingga tidak optimal meningkatkan produksi leukosit.

Kelompok T1 menunjukkan dinamika yang hampir sama dengan T0, hanya saja total leukosit pada fase diestrus memiliki selisih cukup jauh dengan proestrus serta fase awal estrus (72 jam setelah spon vagina dilepas) memiliki selisih yang tidak terpaut jauh dengan fase estrus lainnya. Jumlah leukosit tertinggi justrus berada pada awal fase metestrus (120 jam setelah spon vagina dilepas) dan menurun drastis 24 jam berikutnya. Total leukosit yang cukup tinggi saat fase diestrus dikarenakan keberadaan bakteri yang menumpuk di bagian vagina yang tidak dapat masuk akibat serviks menutup (sekresi lendir tidak terjadi) pada fase ini, sehingga leukosit-leukosit baru dirangsang pembentukannya oleh leukosit dewasa untuk melawan bakteri-bakteri tersebut.

Tabel 2. Total Leukosit Rusa Timor pada Tiap Fase Berahi

\begin{tabular}{|c|c|c|c|}
\hline \multirow[b]{2}{*}{ Fase } & \multirow{2}{*}{$\begin{array}{c}\text { Setelah } \\
\text { Pelepasan } \\
\text { Spon }\end{array}$} & \multicolumn{2}{|c|}{ Perlakuan } \\
\hline & & T0 & $\mathrm{T} 1$ \\
\hline & -- (jam) -- & \multicolumn{2}{|c|}{$---\left(/ \mathrm{mm}^{3}\right)---$} \\
\hline Diestrus & 0 & 3.780 & 4.320 \\
\hline Proestrus & 24 & 3.760 & 3.850 \\
\hline Estrus & 72 & 2.540 & 4.900 \\
\hline Estrus & 84 & 5.500 & 6.780 \\
\hline Estrus & 96 & 4.700 & 5.240 \\
\hline Estrus & 108 & 5.620 & 5.210 \\
\hline Metestrus & 120 & 4.900 & 7.000 \\
\hline Metestrus & 144 & 4.160 & 3.267 \\
\hline
\end{tabular}

Lestari (2015) menyatakan bahwa proses pembentukan leukosit disebut juga dengan leucopoiesis yang dirangsang oleh adanya colony stimulating (factor perangsang koloni) yang dihasilkan oleh leuosit dewasa. Paccola et al. (2013) menyatakan bahwa leukosit banyak ditemukan pada akhir fase metestrus dan diestrus karena rangsangan progesteron yang mendorong neutrofil sebagai salah satu jenis dari leukosit ke vagina untuk proses fagositosis, sehingga juga mengakibatkan peningkatan jumlah leukosit secara keseluruhan. Analisis statistik menunjukkan bahwa total leukosit Rusa Timor pada tiap fase berahi antara kelompok dengan dan tanpa suplementasi mineral tidak berbeda nyata $(\mathrm{p} \geq 0.05)$. Hal ini dapat disebabkan karena kandungan mineral darah pada kelompok T1 tidak jauh berbeda dengan kelompok T0 setelah diberi perlakuan yaitu Mg: 2.581 dan $2.163 \mathrm{mg} / \mathrm{dl}, \mathrm{Zn}: 1.496$ dan $1.383 \mathrm{mg} / \mathrm{l}$, serta Se: 0.1646 dan $0.1376 \mathrm{mg} / \mathrm{l}$. Menurut Mulyaningsih dan Sugiarto (2013) kadar $\mathrm{Zn}$ dan Se dalam darah minimal 4,15 dan $0,04 \mu \mathrm{g} / \mathrm{g}$ dengan batas maksimal 78,09 dan $1,48 \mu \mathrm{g} / \mathrm{g}$. berdasarkan nilai standar tersebut, dapat dikatakan bahwa unsur mineral, terutama $\mathrm{Zn}$ belum terpenuhi di dalam tubuh rusa yang diteliti. Kadar yang tidak jauh berbeda antara kedua kelompok menjadi penyebab tidak berpengaruh suplemetasi mineral ini dalam meningkatkan total leukosit.

\section{Diferensial Leukosit}

\section{Neutrofil}

Dinamika persentase neutrofil pada tiap fase berahi disajikan dalam tabel berikut.

Tabel 3. Persentase Neutrofil Rusa Timor pada Tiap Fase Berahi

\begin{tabular}{|c|c|c|c|}
\hline \multirow{2}{*}{ Fase } & \multirow{2}{*}{$\begin{array}{c}\text { Setelah } \\
\text { Pelepasan Spon }\end{array}$} & \multicolumn{2}{|c|}{ Perlakuan } \\
\hline & & T0 & $\mathrm{T} 1$ \\
\hline & -- (jam) -- & \multicolumn{2}{|c|}{--- (\%) --- } \\
\hline Diestrus & 0 & 30.8 & 50.3 \\
\hline Proestrus & 24 & 49.0 & 46.0 \\
\hline Estrus & 72 & 48.7 & 43.3 \\
\hline Estrus & 84 & 59.9 & 58.6 \\
\hline Estrus & 96 & 62.4 & 60.8 \\
\hline Estrus & 108 & 55.9 & 58.5 \\
\hline Metestrus & 120 & 59.5 & 50.8 \\
\hline Metestrus & 144 & 51.9 & 41.5 \\
\hline
\end{tabular}


Pada kelompok T0, secara umum persentase pada fase estrus cenderung lebih tinggi dibandingkan fase lainnya, meskipun pada fase metestrus persentase neutrofil juga cukup tinggi, disusul fase proestrus dan paling rendah berada pada fase diestrus. Hal yang sedikit berbeda terjadi pada kelompok T1 dimana fase diestrus bukanlah merupakan fase dengan persentase neutrofil terendah, melainkan pada awal fase estrus. (jam ke-72 setelah spon vagina dilepas). Neutrofil meningkat saat estrus berkaitan dengan fungsi fagositosis (memakan) bakteri. Kondisi serviks yang membuka saat estrus akibat adanya sekresi lendir serviks mengkibatkan kontaminasi bakteri dari luar sangat tiggi, sehingga upaya tercepat untuk menghapus atau menghilangkan bakteri tersebut adalah dengan memakan (memfagosit) bakteri tersebut. Ahmadi et al. (2000) menyatakan bahwa pada saat serviks membuka sangat memungkinkan bakteri untuk masuk ke uterus, sehingga diberikan respon dengan memicu migrasi leukosit menuju lendir serviks untuk melakukan fagositosis.

Analisis statistik menunjukkan hasil tidak berbeda nyata pada persentase neutrofil antara kedua kelompok $(\mathrm{p} \geq 0.05)$. Hal ini dapat disebabkan karena kandungan mineral darah pada kelompok T1 tidak jauh berbeda dengan kelompok T0 setelah diberi perlakuan, yaitu $\mathrm{Mg}$ : 2.581 dan $2.163 \mathrm{mg} / \mathrm{dl}$, Zn: 1.496 dan $1.383 \mathrm{mg} / \mathrm{l}$, serta Se: 0.1646 dan $0.1376 \mathrm{mg} / \mathrm{l}$. Kadar mineral yang tidak jauh berbeda antara kedua kelompok inilah yang menjadi penyebab tidak berpengaruhnya suplemetasi mineral ini dalam meningkatkan menurunkan jumlah neutrofil, terutama unsur $\mathrm{Mg}$. Kadar $\mathrm{Mg}$ yang cukup akan membantu tubuh menjalankan fungsi imunitas. Menurut Tam (2003) defisiensi $\mathrm{Mg}$ pada tikus dapat menyebabkaan peningkatan jumlah polimorfonuklear (PMN) neutrofil guna akitivitas fagositosis.

\section{Eosinofil}

Rata-rata persentase eosinofil pada kelompok T0 menunjukkan nilaicukup tinnggi pada fase proestrus, nilai menengah pada fase estrus, dan terendah pada fase metestrus, serta mengalami puncaknya pada fase diestrus. sedangkan pada kelompok T1, persentase eosinofil pada fase estrus cenderung lebih tinggi, fase proestrus cenderung lebih rendah, serta metestrus dan diestrus menunjukkan fluktuasi yang sama dengan kelompok T0 meskipun nilainya sedikit berbeda. Tingginya persentase eosnofil pada fase diestrus disebabkan karena konsentrasi estrogen pada fase ini sangat rendah, sehingga tidak mampu mempengaruhi keberadaan eosinofil. Eosinofil dan estrogen memiliki hubungan timbal balik negative, di mana estrogen menekan eosinofil. Menurut Pardede dan Siahaan (2014) eosinofil terakumulasi pada saat periode diestrus. Menurut Echinard et al. (2011) estrogen menghambat akumulasi eosinofil peritoneal, sehingga menurunkan jumlah eosinofil dalam darah.

Tabel 4. Persentase Eosinofil Rusa Timor pada Tiap Fase Berahi

\begin{tabular}{lccc}
\hline \multirow{2}{*}{ Fase } & Setelah & \multicolumn{2}{c}{ Perlakuan } \\
\cline { 3 - 4 } & $\begin{array}{c}\text { Pelepasan } \\
\text { Spon }\end{array}$ & T0 & T1 \\
\hline Diestrus & -- (jam) -- & $---(\%)$ & --- \\
Proestrus & 0 & 10.7 & 10.6 \\
Estrus & 24 & 9.6 & 8.6 \\
Estrus & 72 & 8.3 & 7.0 \\
Estrus & 84 & 5.8 & 7.0 \\
Estrus & 96 & 8.0 & 7.4 \\
Metestrus & 108 & 7.1 & 6.5 \\
Metestrus & 120 & 5.6 & 8.8 \\
\hline
\end{tabular}

Analisis statistik menunjukkan persentase eosinofil antara kelompok dengan dan tanpa suplementasi mineral tidak berbeda nyata $(p \geq 0.05)$. Hal ini dapat disebabkan karena kandungan mineral darah pada kelompok T1 tidak jauh berbeda dengan kelompok T0 setelah diberi perlakuan yaitu Mg: 2.581 dan $2.163 \mathrm{mg} / \mathrm{dl}, \mathrm{Zn}: 1.496$ dan $1.383 \mathrm{mg} / \mathrm{l}$, serta Se: 0.1646 dan $0.1376 \mathrm{mg} / 1$. Menurut Mulyaningsih dan Sugiarto (2013) kadar $\mathrm{Zn}$ dan Se dalam darah minimal 4,15 dan $0,04 \mu \mathrm{g} / \mathrm{g}$ dengan batas maksimal 78,09 
dan $1,48 \mu \mathrm{g} / \mathrm{g}$. berdasarkan nilai standar tersebut, dapat dikatakan bahwa unsur mineral, terutama $\mathrm{Zn}$ belum terpenuhi di dalam tubuh rusa yang diteliti. Kadar yang tidak jauh berbeda antara kedua kelompok menjadi penyebab tidak berpengaruh suplemetasi mineral, terutama $\mathrm{Zn}$ dalam meningkatkan persentase eosinofil. Widhyari et al. (2014) menyatakan bahwa pemberian unsur mineral $\mathrm{Zn}$ sebanyak 60 maupun 120 ppm tidak mempengaruhi persentase eosinofil, basofil maupun monosit.

\section{Basofil}

Fluktuasi persentase basofil pada tiap fase berahi sangat jelas terlihat dan terdapat perbedaan antara kedua kelompok. Rata-rata persentase basofil pada kelompok T0 cenderung tidak stabil selama fase estrus, cukup rendah pada fase metestrus dan proestrus, serta paling tinggi pada fase diestrus. sedangkan pada kelompok T1 ratarata persentase basofil pada fase estrus cenderung lebih tinggi, disusul metestrus, proestrus dan diestrus tergolong rendah. Basofil merupakan salah satu prekursor pemebentuk FSH dan LH yang berkonsentrasi tinggi saat proestrus dan awal estrus. sehingga persentase basofil seharusnya juga menunjukkan nilai yang tinggi. Staf Pengajar Departemen Farmakologi Fakultas Kedokteran Universitas Sriwijaya (2004) menyatakan bahwa FSH dan LH dibentuk oleh sel basofil.

Tabel 5. Persentase Basofil Rusa Timor pada Tiap Fase Berahi

\begin{tabular}{lccc}
\hline \multirow{2}{*}{ Fase } & Setelah & \multicolumn{2}{c}{ Perlakuan } \\
\cline { 3 - 4 } & Pelepasan & \multicolumn{2}{c}{} \\
& Spon & T0 & T1 \\
\hline Diestrus & $--($ jam) & $----(\%)$ & --- \\
Proestrus & 0 & 19.5 & 5.3 \\
Estrus & 24 & 5.4 & 7.0 \\
Estrus & 72 & 10.3 & 9.3 \\
Estrus & 84 & 4.1 & 3.3 \\
Estrus & 108 & 6.5 & 6.3 \\
Metestrus & 120 & 4.3 & 4.2 \\
Metestrus & 144 & 7.2 & 6.5 \\
\hline
\end{tabular}

Analisis statistik menunjukkan persentase basofil antara kelompok dengan dan tanpa suplementasi mineral tidak berbeda nyata $(p>0.05)$. Hal ini dapat disebabkan karena kandungan mineral darah pada kelompok T1 tidak jauh berbeda dengan kelompok T0 setelah diberi perlakuan yaitu Mg: 2.581 dan $2.163 \mathrm{mg} / \mathrm{dl}, \mathrm{Zn}: 1.496$ dan $1.383 \mathrm{mg} / \mathrm{l}$, serta Se: 0.1646 dan $0.1376 \mathrm{mg} / 1$. Menurut Mulyaningsih dan Sugiarto (2013) kadar $\mathrm{Zn}$ dan Se dalam darah minimal 4,15 dan $0,04 \mu \mathrm{g} / \mathrm{g}$ dengan batas maksimal 78,09 dan $1,48 \mu \mathrm{g} / \mathrm{g}$. berdasarkan nilai standar tersebut, dapat dikatakan bahwa unsur mineral, terutama $\mathrm{Zn}$ belum terpenuhi di dalam tubuh rusa yang diteliti. Kadar yang tidak jauh berbeda antara kedua kelompok menjadi penyebab tidak berpengaruh suplemetasi mineral, terutama $\mathrm{Zn}$ dalam meningkatkan basofil. Widhyari et al. (2014) menyatakan bahwa pemberian unsur mineral Zn sebanyak 60 maupun 120 ppm tidak mempengaruhi persentase eosinofil, basofil maupun monosit.

\section{Monosit}

Rata-rata persentase monosit pada kelompok T0 menunjukkan nilai yang tidak jauh berbeda pada tiap fasenya dengan nilai tertinggi berada pada fase proestrus, dan disusul fase metestrus. Pada fase estrus persentase sel ini cenderung tidak stabil dan berada pada kisaran menengah hingga tinggi, dan diestrus juga menunjukkan nilai tengah. Pada kelompok, T1 metestrus adalah fase dengan persentase monosit tertinggi, disusul proestrus, serta estrus dan diestrus cenderung lebih rendah. Persamaan dari kedua kelompok adalah pada fase estrus menunjukkan angka yang cenderung rendah. Hal ini dapat disebabkan karena estrogen adakan menekan produksi monosit. Bouman et al. (2001) menyatakan bahwa terjadi peningkatan jumlah monosit pada fase luteal dan selama masa kebuntingan dibandingkan fase folikular. Menurut Thongngarm et al. (2003) estrogen menurunkan angka monosit karena hormon ini merangsang mitosis dan apoptosis pada monosit. 
Tabel 6. Persentase Monosit Rusa Timor pada Tiap Fase Berahi

\begin{tabular}{|c|c|c|c|}
\hline \multirow{2}{*}{ Fase } & \multirow{2}{*}{$\begin{array}{l}\text { Setelah } \\
\text { Pelepasan } \\
\text { Spon }\end{array}$} & \multicolumn{2}{|c|}{ Perlakuan } \\
\hline & & T0 & $\mathrm{T} 1$ \\
\hline & -- (jam) -- & \multicolumn{2}{|c|}{--- (\%) --- } \\
\hline Diestrus & 0 & 5.8 & 7.1 \\
\hline Proestrus & 24 & 8.1 & 9.9 \\
\hline Estrus & 72 & 6.2 & 9.8 \\
\hline Estrus & 84 & 5.3 & 5.5 \\
\hline Estrus & 96 & 7.4 & 6.0 \\
\hline Estrus & 108 & 3.9 & 4.4 \\
\hline Metestrus & 120 & 7.3 & 10.8 \\
\hline Metestrus & 144 & 8.1 & 14.8 \\
\hline
\end{tabular}

Analisis statistik menunjukkan bahwa persentase monosit antara kedua kelompok tidak berbeda nyata $(p \geq 0.05)$. Hal ini dapat disebabkan karena kandungan mineral darah pada kelompok T0 hampir sama dengan kelompok T1 setelah diberi perlakuan yaitu $\mathrm{Mg}$ : 2.581 dan $2.163 \mathrm{mg} / \mathrm{dl}, \mathrm{Zn}: 1.496$ dan $1.383 \mathrm{mg} / \mathrm{l}$, serta Se: 0.1646 dan $0.1376 \mathrm{mg} / \mathrm{l}$. Menurut Mulyaningsih dan Sugiarto (2013) kadar $\mathrm{Zn}$ dan Se dalam darah minimal 4,15 dan $0,04 \mu \mathrm{g} / \mathrm{g}$ dengan batas maksimal 78,09 dan $1,48 \mu \mathrm{g} / \mathrm{g}$. berdasarkan nilai standar tersebut, dapat dikatakan bahwa unsur mineral, terutama $\mathrm{Zn}$ belum terpenuhi dalam tubuh rusa yang diteliti. Kadar yang hampir sama antara kedua kelompok menjadi penyebab tidak berpengaruh suplemetasi mineral, terutama $\mathrm{Zn}$ dalam meningkatkan persentase monosit. Widhyari et al. (2014) menyatakan bahwa pemberian unsur mineral Zn sebanyak 60 maupun 120 ppm tidak mempengaruhi persentase eosinofil, basofil maupun monosit.

\section{Limfosit}

Dinamika persentase limfosit menunjukkan nilai yang cukup berfluktuasi pada tiap fase berahi (Tabel 7). Rata-rata persentase limfosit kelompok T0 selama fase estrus cenderung lebih rendah dibandingkan fase lainnya, dan tertinggi berada pada diestrus. Fenomena berbeda terjadi pada kelompok T1 dimana pada fase estrus, limfosit menunjukkan nilai yang cukup tinggi meskipun tidak terpaut jauh dibandingkan fase lainnya. Tabel tersebut menunjukkan persentase tertinggi pada kelompok T0 berada fase diestrus, sedangkan pada kelompok T1 berada pada fase estrus jam ke-72 setelah spon vagina dilepas. Limfosit adalah sel yang memiliki reseptor hormon, estrogen. Estrogen mengalami peningkatan drastis ketika folikel telah matang (folikel de Graaf) hingga menjelang ovulasi, yakni pada estrus hingga awal metestrus. Sekresi estrogen yang melimpah akan menginduksi terjadinya proliferasi (penggandaan) sel limfoid menjadi beberapa turunan sel limfosit, sehingga menyebabkan jumlah sel limfosit dalam darah kana meningkat. Aimaretti et al. (2011) menyatakan bahwa salah satu varian ER $\alpha$ yang disebut ER $\alpha 46$ terdapat pada permukaan sel limfosit dan menjadi mediator estrogen dalam menginduksi proliferasi sel $\mathrm{T}$ dan sel NK, tetapi tidak dengan sel B.

Tabel 7. Persentase Limfosit Rusa Timor pada Tiap Fase Berahi

\begin{tabular}{|c|c|c|c|}
\hline \multirow[b]{2}{*}{ Fase } & \multirow{2}{*}{$\begin{array}{c}\text { Setelah } \\
\text { Pelepasan } \\
\text { Spon }\end{array}$} & \multicolumn{2}{|c|}{ Perlakuan } \\
\hline & & T0 & T1 \\
\hline & -- (jam) -- & \multicolumn{2}{|c|}{--- $(\%)$--- } \\
\hline Diestrus & 0 & 33.2 & 26.9 \\
\hline Proestrus & 24 & 27.9 & 28.6 \\
\hline Estrus & 72 & 26.5 & 30.8 \\
\hline Estrus & 84 & 24.9 & 25.6 \\
\hline Estrus & 96 & 15.7 & 19.5 \\
\hline Estrus & 108 & 25.3 & 26.5 \\
\hline Metestrus & 120 & 21.3 & 23.0 \\
\hline Metestrus & 144 & 27.4 & 27.8 \\
\hline
\end{tabular}

Rendahnya limfosit pada fase estrus juga disebabkan karena pada fase ini terjadi kotaminasi sangat besar dari bakteri-bakteri dan benda asing melalui serviks yang membuka akibat sekresi lendir serviks. Selain tindakan fagositosis oleh neutrofil, jenis sel lain yang juga berperan dalam melawan bakteri adalah limfosit. Limfosit berperan membentuk antibodi berupa immunoglobulin. Limfosit akan berdiferensiasi menjadi bentuk sel limfosit B (sel B) sebagai respon terhadap antigenantigen yang masuk. Menurut Zunikhah 
(2010) jenis limfosit yang penting dalam sistem pertahanan tubuh salah satunya sel B guna memproduksi imonoglobulin yang akan masuk sistem sirkulasi dan sistem limfa untuk menempel pada antigen dan mengenalinya agar dapat difagosit oleh sel imun.

Analisis statistik menunjukkan persentase limfosit antara kedua kelompok tidak berbeda nyata $(p \geq 0.05)$. Hal ini dapat disebabkan karena mineral yang tercerna pada kelompok T1 lebih rendah dibandingkan T0 (Mg: $0.792 \mathrm{mg} / \mathrm{dl}, \mathrm{Zn}$ : $0.516 \mathrm{mg} / \mathrm{l}$, dan Se: $0.0504 \mathrm{mg} / \mathrm{l})$ jika dibandingkan kelompok T0 (Mg: 1.172 $\mathrm{mg} / \mathrm{dl}, \mathrm{Zn}: 0.713 \mathrm{mg} / \mathrm{l}$, dan Se: $0.0726 \mathrm{mg} / \mathrm{l}$ ), sehingga kadar mineral dalam darah pada kelompok T1 masih belum memenuhi standar normal, yaitu $\mathrm{Mg}: 2.163 \mathrm{mg} / \mathrm{dl}, \mathrm{Zn}$ : $1.383 \mathrm{mg} / \mathrm{l}$, dan Se: $0.1376 \mathrm{mg} / \mathrm{l}$. Menurut Mulyaningsih dan Sugiarto (2013) kadar Zn dan Se dalam darah minimal 4,15 dan 0,04 $\mu \mathrm{g} / \mathrm{g}$ dengan batas maksimal 78,09 dan 1,48 $\mu \mathrm{g} / \mathrm{g}$. berdasarkan nilai standar tersebut, dapat dikatakan bahwa unsur mineral $\mathrm{Zn}$ belum terpenuhi di dalam tubuh rusa yang diteliti, akibatnya $\mathrm{Zn}$ belum optimal dalam memicu produksi leukosit. Rink dan Kirchner dalam Widhyari et al. (2014) menyatakan bahwa zinc mampu meningkatkan limfosit darah melalui peningkatan produksi limfokin yang mengakibatkan limfosit mampu berdiferensiasi dan berproliferasi. Hasil penelitian Fatimah (2006) juga menunjukkan bahwa keadaan defisien zinc akan langsung menurunkan produksi limfosit $\mathrm{T}$.

\section{KESIMPULAN DAN SARAN}

\section{Simpulan}

Berdasarkan hasil penelitian dapat disimpulkan bahwa panjang tiap fase berahi pada tiap rusa berbeda. Dinamika total leukosit Rusa Timor menunjukkan nilai paling tinggi pada fase estrus, begitu pula dengan neutrofil, basofil dan limfosit, sedangkan eosinofil dan monosit paling tinggi berada pada fase proestrus dan metestrus. Suplementasi mineral Mg, Zn, dan
Se tidak berpengaruh nyata dalam merubah jumlah total leukosit maupun diferensial sel Rusa Timor pada tiap fase berahi.

\section{Saran}

Sebaiknya penangkar dapat lebih memperhatikan pakan yang akan diberikan kepada Rusa Timor terutama dari segi kandungan nutrisi mineralnya agar kebutuhan nutrisinya dapat terpenuhi termasuk kebutuhan untuk bereproduksi.

\section{UCAPAN TERIMA KASIH} kepada:

Penulis mengucapkan terima kasih

1. Direktorat Penelitian dan Pengabdian kepada Masyarakat dan Direktorat Jenderal Pendidikan Tinggi Kementerian Riset dan Teknologi Republik Indonesia yang telah mendukung kegiatan penelitian ini melalui dana penelitian fundamental 2016 .

2. Mas Kelik Isharyudhono, S.T. yang telah membantu dalam pembuatan alat pencetak mineral blok.

3. Mas Alam Sriwijaya, S.Pt. yang telah memberi ijin peminjaman beberapa alat penelitian dan mengajarkkan beberapa metode terkait penelitian ini.

4. Mas Lilik Krismiyanto, S.Pt., M.Si. yang telah menyediakan bahan mineral untuk penelitian ini.

\section{DAFTAR PUSTAKA}

Ahmadi, M.R., S. Nafizi and S. Ahmadi. 2000. Relationship of difeerential leukocyte count in uterine cervical mucus and blood with reproductive function of postpartum cows. Iranian J. of Vet. Research. 1 (2): 107-117.

Aimaretti, G., P. Marrullo and R. Prodem. 2011. Update on Mechanism of Hormone Action - Focus on Metabolism, Growth and Reproduction. Intech, Europe.

Bouman, A., M.J. Heineman and M.M. Faas. 2001. The immune response during the luteal phase of the ovarian cycle: 
increasing sensitivity of human monocyte to endotoxin. Fertile Steril. 76 (3): 555-559.

Burney, P.G.J. 2000. Epidemiology. In: Asthma. $4^{\text {th }}$ ed. Oxford University Press, New York.

Echinard, V.D., B. Calippe, A.B. Gale. C. Fontaine, F. Lenfant, F. Tremollieres, F. Bayard, J.C. Guery, J.F. Arnai dan P. Gourdy. 2011. Estradiol administration controls eosinophilia through estrogen receptor- $\alpha$ activation during acute peritoneal inflammation. J. of Leukoc Biol. 90 (1): 145-154.

Fatimah. 2006. Respon imunitas yang rendah pada tubuh manusia usia lanjut. Makara Kedokteran. 10 (1): 47-53.

Kurniawan, L.B., U. Bahrun, E.R. Darmawaty dan M. Arif. 2015. Pengaruh jumlah leukosit terhadap mortalitas pasien infark miokard akut selama perawatan. CDK-233. 42 (10): 727-730.

Muljono, A.T. 2001. Persentase Jenis-jenis Lekosit pada Tiap Fase Siklus Reproduksi Tikus Putih (Rattus sp.). Fakultas Kedokteran Hewan Institut Pertanian Bogor, Bogor. (Skripsi Sarjana Kedokteran Hewan).

Mulyaningsih, T.R. dan W. Sugiarto. 2013. Analisis unsur mineral dan korelasinya dalam darah penderita hipertensi dan normal dengan teknik AAN. J.Tek.Reaktor.Nukl. 15 (3): 150-158.

Paccola, C.C., C.G. Resende, T. Stumpp, S.M. Miraglia and I. Cipriano. 2013. The rat estrous cycle revisited: a quantitative and qualitative analysis. Anim.Reprod. 10 (4): 677-683.

Pardede, D.K.B. dan D. Siahaan. 2014. Eosinopenia sebagai penanda diagnosis sepsis. CDK-221. 41 (10): 741-744.

Perez, M.C., E.E. Futrh, P.D. Matzumura and R. Lyttle. 1996. Role of eosinophils in uterine responses to estrogen. Bio. of Reprod. 54 (1): 249-254.

Roth, J.A., M.L. Kaeberle dan W.H. Hsu. 1982. Effects of estradiol and progesterone on lymphocyte and neutrophil function in steers. Infection and Immunity. 35 (3): 997-1002.

Shanti, G., D. Balasubramanyam, P. Thangaraju dan R. Srinivasa. 2012. Hematological studies in Indian deer Axix axis. Tamilnadu J.Vet \& Anim.Sci. 8 (6): 351-355.

Staf Pengajar Departemen Farmakologi Fakultas Kedokteran Universitas Sriwijaya. 2004. Kumpulan Kuliah Farmakologi. EGC, Jakarta.

Tam, M., S. Gomez, M. Gonzalesz-Gross dan A. Marcos. 2003. Possible roles of magnesium on the immune system. Europ. J. of Clin. Nut. 57 (1): 1193 1197.

Thongngarm, T., J.K. Jenkins dan K. Ndebele. 2003. Estrogen dan progesterone modulate monocyte cell cycle progression and apoptosis. Am. J. of Reprod. Imm.. 49 (3): 129-138.

Tjendrajaja, T.M. 2011. Leukosit sebagai salah satu parameter kesehatan rusa timor (Cervus timorensis) di usaha penangkaran rusa timor kecamatan Dawe kabupaten Kudus. Fakultas Kedokteran Hewan Institut Pertanian Bogor, Bogor. (Skripsi Sarjana Kedokteran Hewan).

Uhart, M.M., A.R. Vila, M.S. Beade, A. Balcarce dan W.B. Karesh. 2003. Health evalua-tion of Pampas Deer (Ozoto-ceros bezoarticus celer) at Campos del Tuyu Wildlife Reserve, Argentina. J. of Wildlife Dis. 39 (4): 887-893.

Widhyari, S.D., A. Esfandiari, A. Wijaya, R. Wulansari, S. Widodo dan L. Maylina. 2014. Efek penambahan mineral Zn terhadap gambaran hematologi pada 
anak sapi Frisian Holstein. JIPI. 19 (3): 150-155.

Zunikhah. 2010. Efektivitas Zat Gizi Mikro Seng (Zn) sebagai Imunostimulan terhadap Produksi Reactive Oxygen
Intermediate (ROI) pada Mencit BALB/C yang Diinfeksi. Fakultas Matematika dan Ilmu Pengetahuan Alam Universitas Negeri Semarang, Semarang. (Skripsi Sarjana Sains). 